\title{
Redescription of two poorly known Arctic Hilaira species (Aranei: Linyphiidae) with notes on species grouping
}

\author{
Переописание двух малоизвестных арктических видов рода \\ Hilaira (Aranei: Linyphiidae) с комментариями о группах видов
}

\author{
Yuri M. Marusik ${ }^{1-3}$, Anna A. Nekhaeva ${ }^{4}$ \\ Ю.М. Марусик ${ }^{1-3}$, А.А. Нехаева ${ }^{4}$
}

\footnotetext{
${ }^{1}$ Institute for Biological Problems of the North RAS, Portovaya Str. 18, Magadan 685000, Russia. E-mail: yurmar@mail.ru

${ }^{2}$ Department of Zoology \& Entomology, University of the Free State, Bloemfontein 9300, South Africa.

${ }^{3}$ Zoological Museum, Biodiversity Unit, University of Turku, FI-20014, Finland.

${ }^{4}$ A.N. Severtsov Institute of Ecology and Evolution, Russian Academy of Sciences, Leninsky prospekt 33, Moscow 119071, Russia.

${ }^{1}$ Институт биологических проблем Севера, ДВО РАН, Портовая 18, Магадан 685000, Россия

${ }^{4}$ Институт проблем экологии и эволюции им. А.Н. Северцова РАН, Ленинский проспект 33, Москва 119071, Россия.
}

KEY WORDS: spider, Erigoninae, Siberia, Asia, Palaearctic, Nearctic, distribution.

КЛЮЧЕВЫЕ СЛОВА: паук, Erigoninae, Сибирь, Азия, Палеарктика, Неарктика, распространение.

ABSTRACT. Two poorly known Hilaira species, H. incondita (L. Koch, 1879) and H. proletaria (L. Koch, 1879) are redescribed and their copulatory organs are illustrated in detail by means of digital and SEM photographs. Maps of the known records of two species are provided as well. Species grouping in the genus are briefly discussed.

How to cite this article: Marusik Yu.M., Nekhaeva A.A. 2020. Redescription of two poorly known Arctic Hilaira species (Aranei: Linyphiidae) with notes on species grouping // Arthropoda Selecta. Vol.29. No.1. P.133-140. doi: 10.15298/arthsel. 29.1.12

РЕЗЮМЕ. Переописаны два малоизвестных вида рода Hilaira, распространенные в Арктике - $H$. incondita (L. Koch, 1879) и H. proletaria (L. Koch, 1879). Приведены цифровые и СЭМ-фотографии, иллюстрирующие их копулятивные органы, а также карта распространения обоих видов. Кратко обсуждается структура рода.

\section{Introduction}

Hilaira Simon, 1884 is a medium sized genus of Erigoninae with 25 species distributed in the Holarctic [WSC, 2020]. Although the genus was never a subject of global revision, it is relatively well studied due to publications dealing with European spiders and regional reviews of Siberian species [Eskov, 1981, 1987; Marusik, Tanasevitch, 2003]. Only two species of $\mathrm{Hi}^{-}$ laira are known from one sex (female). None of the species is restricted to the Nearctic. All Hilaira species known from the North America occur also in Siberia or across the whole Palaearctic. Of 25 species known in the genus only three, H. banini Marusik et Tanasevitch, 2003 (Mongolia), H. dapaensis Wunderlich, 1983 (Ne- pal) and H. tuberculifera Sha et Zhu, 1995 (Northeastern China) are not found in Russia. Most of the species occurring in Asia can be more or less easily identified thanks to the illustrations provided in original publications except for three species inhabiting the tundra zone of Siberia and the Nearctic: H. hyperborea Kulczyński, 1908, $H$. incondita (L. Koch, 1879) and $H$. proletaria (L. Koch, 1879). All these species have been illustrated by Kulczyński [1908, 1916] more than a century ago, and only for the $H$. proletaria female are there relatively recent illustrations [Holm 1973: 85, figs. 36, 37]. During our work with spiders inhabiting tundra zone, we faced the problem of identifying the two latter species. Thus, the goal of this paper is the redescription of $H$. incondita and $H$. proletaria based on freshly collected specimens.

\section{Material and methods}

Photographs were taken using an Olympus SZX16 stereomicroscope with a Canon-7D camera and prepared using Zerene Stacking software. Scanning electron micrographs were made using the SEM JEOL JSM-5200 scanning microscope at the Zoological Museum, University of Turku, Finland. Leg segments were measured on the dorsal side. All measurements are given in millimetres. The material treated here is deposited in the Zoological Museum of the Moscow State University, Russia (ZMMU) and the Zoological Museum of the University of Turku, Finland (ZMUT).

Taxonomic survey

Hilaira Simon, 1884

Hilaira Simon, 1884: 374. 
Hiliara: Hull, 1932: 109; Eskov, 1981: 1486; 1987: 1020; Saaristo, Marusik, 2004: 209.

TYPE SPECIES. Neriene excisa O. Pickard-Cambridge, 1871 from England.

COMMENTS. Judging from the copulatory organs as well as modification of male carapace and metatarsus I Hilaira is not a monophyletic genus. The genus has three junior synonyms Arctilaira Chamberlin, 1921 (type A. bellans Chamberlin, $1921=H$. vexatrix (O. Pickard-Cambridge, 1877)), Soudinus Crosby et Bishop, 1936 (type S. canaliculatus Crosby et Bishop, $1936=H$. canaliculata (Emerton, 1915)) and Utopiellum Strand, 1901 (type Erigone mirabilis L. Koch, $1879=H$. herniosa (Thorell, 1875)).

The type species differs from most of the species considered in the genus by the shape of the male carapace (Fig. 1G) and unmodified metatarsus I. The male palp of the generotype is similar only to those of $H$. herniosa and $H$. sibirica Eskov, 1987 due to the long ventral apophysis of the 'median plate of the bulb' (sensu Saaristo, Marusik 2004) and elongate dorsal tibial apophysis.

It seems that at least two species are misplaced in the genus, $H$. dapaensis Wunderlich, 1983 from Nepal and $H$. tuberculifera Sha et Zhu, 1995 from China. The former species has a very long and thin tibial apophysis (1.5 times longer than tibia) unknown in other Hilaira species. The latter species has a male palpal tibia with two relatively long dorsal apophyses, an embolic division lacking elongated tailpiece and chelicera lacking retrolateral teeth characters unknown in the rest of Hilaira.

The first species grouping for the whole genus was made by Eskov [1981], who recognized seven groups among 22 species known at that time: excisa, nubigena, herniosa, glacialis, pervicax, frigida and minuta. Eskov [1981] did not mention reasons or criteria for how he delimited each group. Since then the most species rich group, the frigida-group was recognized to be a separate genus Oreoneta Kulczyński, 1894 [Saaristo, Marusik, 2004]. Thereby the number of species known at that time has changed, and we decided to revise species grouping and provide comments on each group.

Arctilaira Chamberlin, 1921 or the Hilaira glacialisgroup is well delimited thanks to the shape of epigyne with well-developed fovea and lateral lobes, and modification of male carapace (raised thoracic part, not a cephalic one). This taxon includes at least nine species: Hilaira banini Marusik et Tanasevitch, 2003; H. gertschi Holm, 1960, H. glacialis (Thorell, 1871), H. jamalensis Eskov, 1981, H. marusiki Eskov, 1987, H. nivalis Holm, 1937, H. nubigena Hull, 1911, H. syrojeczkovskii Eskov, 1981 and H. vexatrix (O. Pickard-Cambridge, 1877).

Three species form a distinct $H$. minuta-group: $H$. gibbosa Tanasevitch, 1982, H. meridionalis Tanasevitch, 2013 and H. minuta Eskov, 1979. Males have rounded cephalic hump (lacking anterior conical or angled edge), palpal tibia without distinct apophysis (present in all other Hilira species groups) and epigynes lack fovea.

Utopiellum Strand, 1901 or the H. herniosa-group includes two species $H$. herniosa (Thorell, 1875) and H. sibirica Eskov, 1987. Female of both species have epigynes with extended bases.

Soudinus Crosby et Bishop, 1936, or H. canaliculatagroup includes only one species, Hilaira canaliculata (Emerton, 1915).

Eskov's [1981] pervicax-group, is known from two species, H. proletaria (L. Koch, 1879) and H. pervicax Hull, 1908 and the name of this group should be called H. prole- taria-group, because $H$. pervicax was described later. This group can be recognized by roundly bent embolus accompanied by membrane. Males of both species have similarly modified carapace and metatarsus I. Females of these species have distinct epigynal fovea.

Eskov's [1981] nubigena-group was first recognized by Holm [1960], who indicated the similarity between H. nubigena Hull, 1911 and $H$. incondita (L. Koch, 1879). This group should be called $H$. incondita to follow year-priority. This group can be easily recognized by the shape of epigyne having lateral lobes of fovea and distinct septum. Males of this group have very massive anterior part of embolic division lacking in other species and short embolus proper.

Three species, Hilaira asiatica Eskov, 1987, H. devitata Eskov, 1987 and H. pelikena Eskov, 1987 have copulatory organs different from other species and therefore we leave them ungrouped. Eskov (1987) placed $H$. asiatica into the H. nubigena-group. Hilaira devitata has not been assigned to any group, and is thought to be something intermediate between $H$. minuta-group and $H$. frigida-group (=Oreoneta Kulczyński, 1894) because embolic division and epigyne are very different from these taxa. The later species, $H$. pelikena was described based on the male only and assigned by Eskov [1987] to the H. glacialis-group, although it has different carapace modification (postocular hump rounded, not angled) and epigyne of this species is also different from all other species belonging to $H$. glacialis-group.

Hilaira hyperborea Kulczyński, 1908 whose male is unknown and female is known from a poor original figure also cannot be grouped with other species. Epigyne of this species is somewhat similar to those in $H$. pelikena and potentially the two species may be synonyms.

\section{Hilaira incondita (L. Koch, 1879)}

Figs. 1A-C, 2, 4, 7.

Erigone incondita L. Koch, 1879: 66, pl. 2, f. 17 ( $\left.\bigcirc^{7}+\right)$.

Hilaira incondita: Kulczyński, 1908: 29, pl. 2, f. 50-51, 61-62 $\left(\sigma^{r}+\right)$.

Hilaira incondita: Kulczyński, 1916: 13, pl. 1, f. 15 (○'o).

MATERIAL EXAMINED. RUSSIA, Nenets Autonomous Okrug: $1 \sigma^{\top} 11$ OP (ZMMU, ZMUT), Kanin Peninsula, env. of Shoina Vill., sea marshes, 12-25.07.2017 (A. Babenko \& A. Nekhaeva); $32 \mathrm{O}^{7} \sigma^{7} 1+$ (ZMMU, ZMUT), Yugorskiy Peninsula, env. of Amderma Vill., sea marshes, 4-18.07.2018 (M. Bizin \& B. Efeikin); Yamalo-Nenets Autonomous Okrug: 4 우 (ZMMU), Gydan Peninsula, Shokalskogo Isl., $72^{\circ} 58^{\prime} \mathrm{N} 74^{\circ} 27^{\prime} \mathrm{E}$, bog with Carex and Shpagnum, August 2016 (A. Nekhaeva \& M. Bizin).

DIAGNOSIS. Hilaira incondita significantly differs from the generotype by lacking long lamellate process of the bulb, having tibial apophysis with claw-like tip ( $v s$. tip rounded), presence of strong spines on metatarsus I in males (vs. lacking) and having distinct epigynal fovea (vs. lacking). Males of this species differ from congeners by comma shaped process (Ep) of the embolic division (Figs. 2A, 4A vs. lacking). Epigyne of $H$. incondita is similar to members of the $H$. glacialis-group in having rounded lobes $(E l)$ of epigyne (Figs. 4G-H), but differs by having a distinct septum (vs. lacking).

DESCRIPTION. Male. Total length 3.0-3.45, carapace 1.4-1.75 long, 1.1-1.3 wide. Carapace, sternum and chelicera brown; legs light brown; abdomen dark grey. Chelicera with 4-5 large prolateral teeth and 2-3 small retrolateral teeth. Tibial spine formula 2222, TmI 0.66-0.74; metatarsus I slightly bent, with ca. 12 spines. 

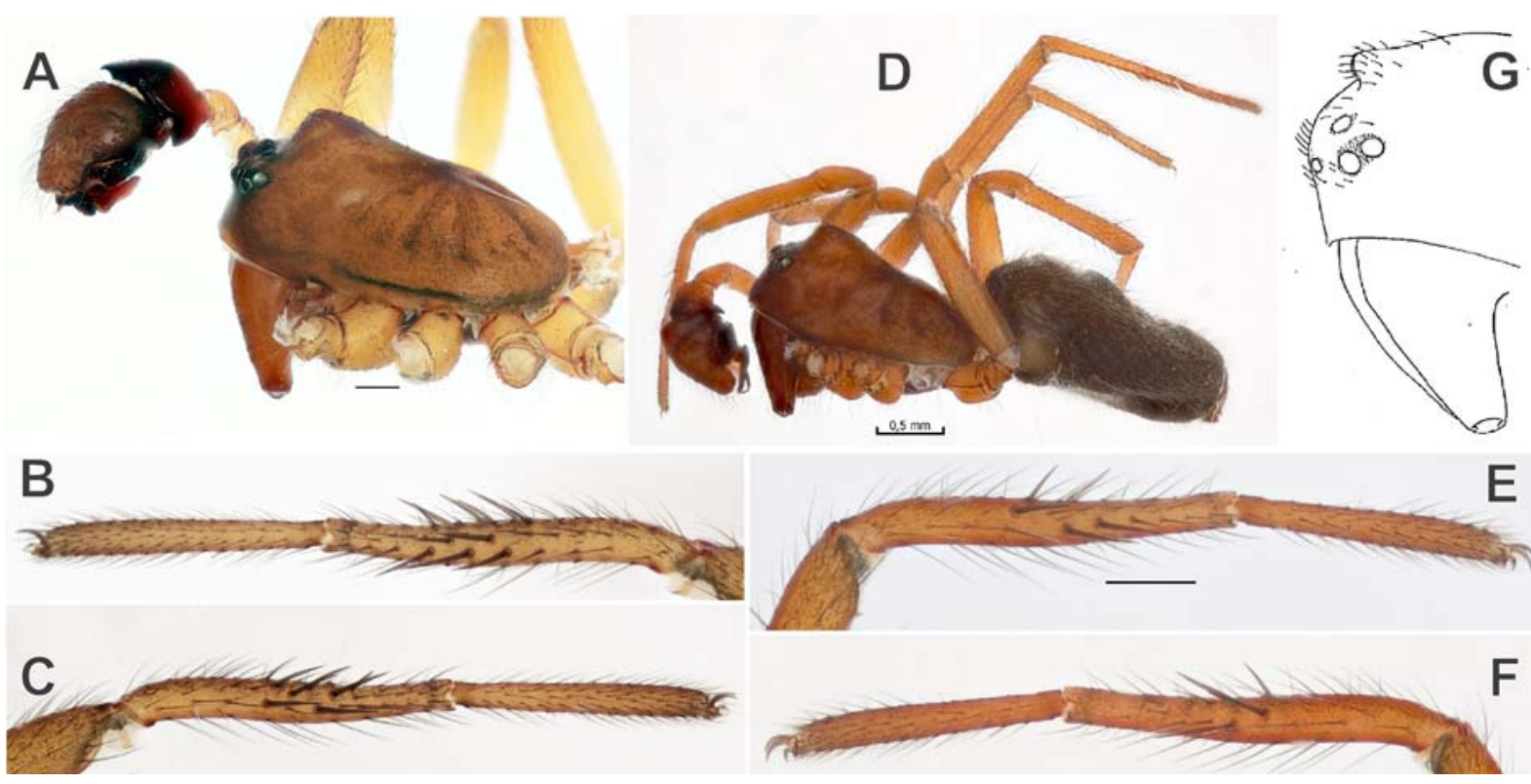

Fig. 1. Males Hilaira incondita (A-C), H. proletaria (D-F) and H. excisa (G). A - prosoma, lateral; D - habitus, lateral; B, F - leg I, retrolateral; C, E - leg I, prolateral; G - anterior part of prosoma, lateral. G - after Wiehle [1956]. Scale $=0.2 \mathrm{~mm}$ if not otherwise indicated.

Рис. 1. Самцы Hilaira incondita (A-C), H. proletaria (D-F) и H. excisa (G). А головогрудь, сбоку; D - габитус, сбоку; В, F нога I, ретролатерально; C, E - нога I, пролатерально; G - передняя часть головогруди, сбоку. G - по Wiehle [1956]. Масштаб 0,2 мм, если не указано иное.

Leg measurements in male/female:

$\begin{array}{lcccccc}\text { Leg } & \mathrm{Fe} & \mathrm{Pa} & \mathrm{Ti} & \mathrm{Mt} & \mathrm{Ta} & \text { Total } \\ \text { I } & 1.1 / 1.1 & 0.4 / 0.4 & 1.0 / 0.9 & 0.8 / 0.8 & 0.6 / 0.6 & 3.9 / 3.8 \\ \text { II } & 1.1 / 1.0 & 0.4 / 0.4 & 0.9 / 0.9 & 0.8 / 0.8 & 0.6 / 0.6 & 3.8 / 3.7 \\ \text { III } & 1.0 / 1.0 & 0.4 / 0.4 & 0.8 / 0.7 & 0.8 / 0.7 & 0.5 / 0.5 & 3.5 / 3.3 \\ \text { IV } & 1.3 / 1.3 & 0.4 / 0.4 & 1.2 / 1.1 & 1.1 / 1.0 & 0.7 / 0.7 & 4.7 / 4.5\end{array}$

Palp as in Figs. 2A-D, 4A-F; femur about 4 times longer than wide, as long as cymbium; tibia with massive dorsal apophysis longer than tibia itself, terminal part of apophysis with claw like tip $(C t)$; cymbium with retrolateral fold $(C f)$; paracymbium with tapering, triangle shaped tip; embolic division complex, with bent tail piece $(T p)$, terminal half with scale like cuticle $(S c)$, longitudinal furrow $(E f)$ and process $(E p)$ encircling embolus proper $(E m)$.

Female. Total length 3.35-3.75, carapace 1.45-1.6 long, $1.05-1.1$ wide. Coloration and chelicera armament as in male. TmI 0.71-0.74.

Epigyne as in Figs. 2E-I, 4G-I; bilobate in ventral view (Figs. 2E-F), with basal depression $(B d)$; lateral margins of fovea with rounded lobes $(E l)$ covering most of the fovea (Fig. 2H-I), or they can be extended dorsally (Fig. 2G); septum $(\mathrm{Se})$ distinct, about 2 times longer than median plate $(\mathrm{Mp})$ length; median plated oval shaped, 2 times wider than long.

DISTRIBUTION. This species has a Siberian-Nearctic range and is known from the Kanin Peninsula (Barents Sea) to Québec (Canada) (Fig. 7). All records of H. incondita lie in the tundra zone.

Hilaira proletaria (L. Koch, 1879) Figs. 1D-F, 3, 5, 6, 7.

Linyphia proletaria L. Koch, 1879: 23, pl. 1, f. 10 ( ( 7 \%). Hilaira zaicewii Kulczyński, 1916: 14, pl. 1, f. 16-17, 19-22 $\left(\sigma^{\top}+\right)$.
Hilaira proletaria: Holm, 1973: 85 , f. $36-37$ (transferred to Hilaira, and synonymized with $H$. zaicewii).

MATERIAL EXAMINED: RUSSIA: $11 O^{7} O^{7}$ (ZMMU, ZMUT) Nenets Autonomous Okrug, Yugorskiy Peninsula, env. of Amderma Vill., sea marshes, 4-18.07.2018 (M. Bizin \& B. Efeikin); 7 O $^{7}$ 6 우 (ZMMU, ZMUT), Yamalo-Nenets Autonomous Okrug, Gydan Peninsula, Shokalskogo Isl., $72^{\circ} 58^{\prime} \mathrm{N} 74^{\circ} 27^{\prime} \mathrm{E}$, seamarshes, August 2016 (A. Nekhaeva \& M. Bizin).

DIAGNOSIS. Hilaira proletaria significantly differs from the generotype by lacking long lamellate process of the bulb, short (shorter than tibia) tibial apophysis (vs. apophysis as long as tibia), presence of strong spines on metatarsus I in males (vs. lacking) and having distinct epigynal fovea (vs. lacking). By the shape of copulatory organs and modification of male carapace it is similar to H. pervicax, but can be separated by shorter tibial apophysis, lack of spine on retrolateral edge of palpal tibia in male ( $v s$. present) and presence of septum in epigyne (vs. absent).

DESCRIPTION. Male. Total length 3.25-3.55, carapace 1.5-1.7 long, 1.15-1.25 wide. Carapace and chelicera brown, legs light brown, abdomen dark grey. Chelicera with 5 large prolateral teeth and 3 small retrolateral teeth. Metatarsus I slightly bent, with 9 spines. Tibial spine formula 2222. TmI 0.69-0.83.

Leg measurements in male/female:

$$
\begin{array}{lllllll}
\text { Leg } & \mathrm{Fe} & \mathrm{Pa} & \mathrm{Ti} & \mathrm{Mt} & \mathrm{Ta} & \text { Total }
\end{array}
$$

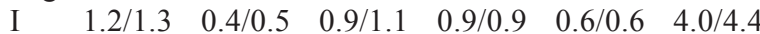

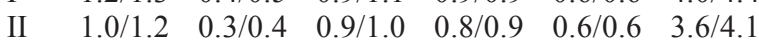

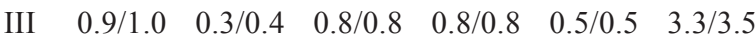
IV $\quad \begin{array}{llllll}1.2 / 1.4 & 0.4 / 0.5 & 1.3 / 1.3 & 1.2 / 1.2 & 0.7 / 0.7 & 4.8 / 5.1\end{array}$

Palp as in Figs. 3A-D, 5, 6E, femur 4 times longer than wide and shorter than cymbium; tibia twice shorter than cymbium, with 3 apophyses: short conical dorso-prolateral $(D a)$, prolateral $(P a)$ and ventro-prolateral $(V a)$; cymbium with distict retrolateral fold; paracymbium massive, with 

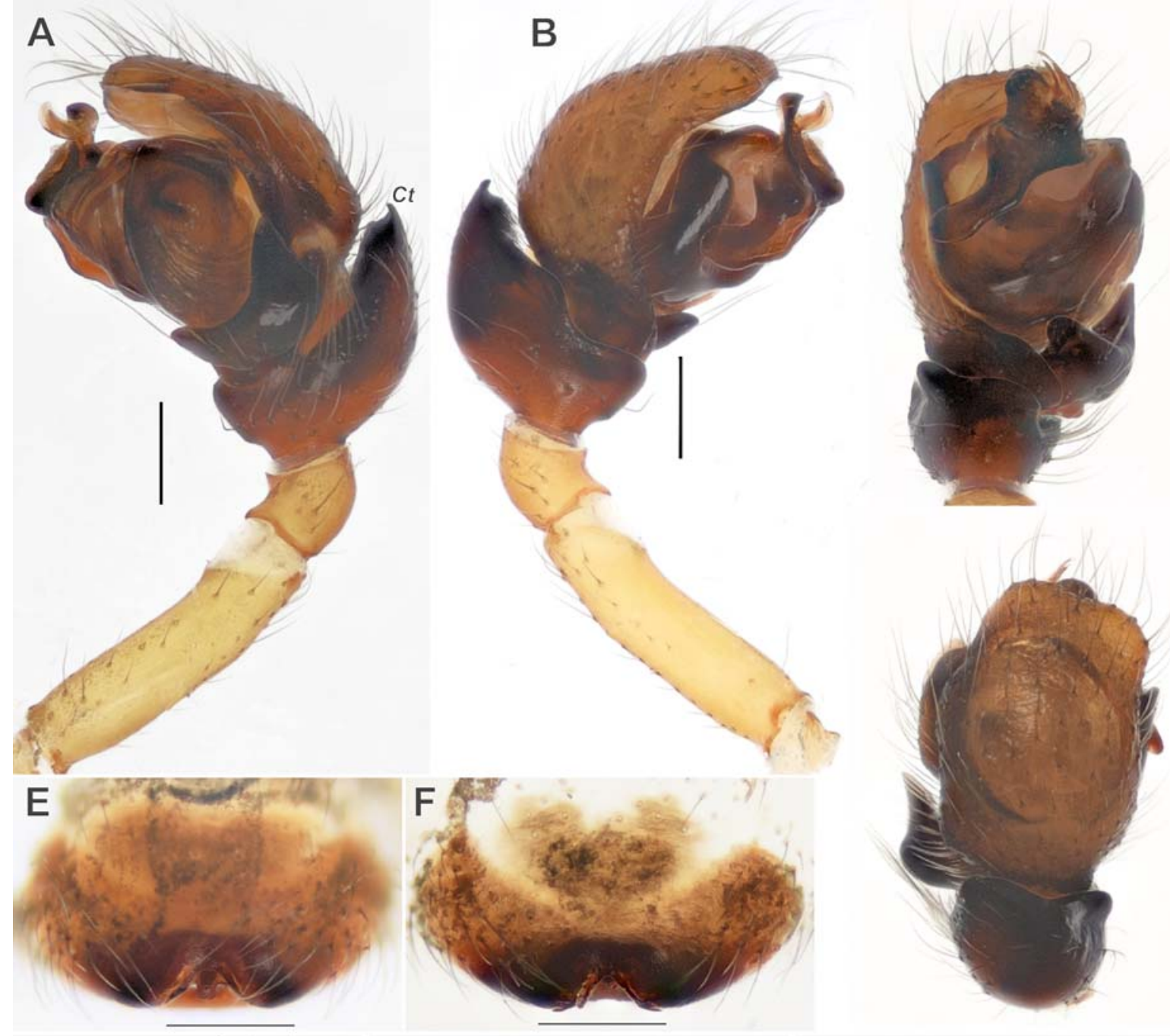

C
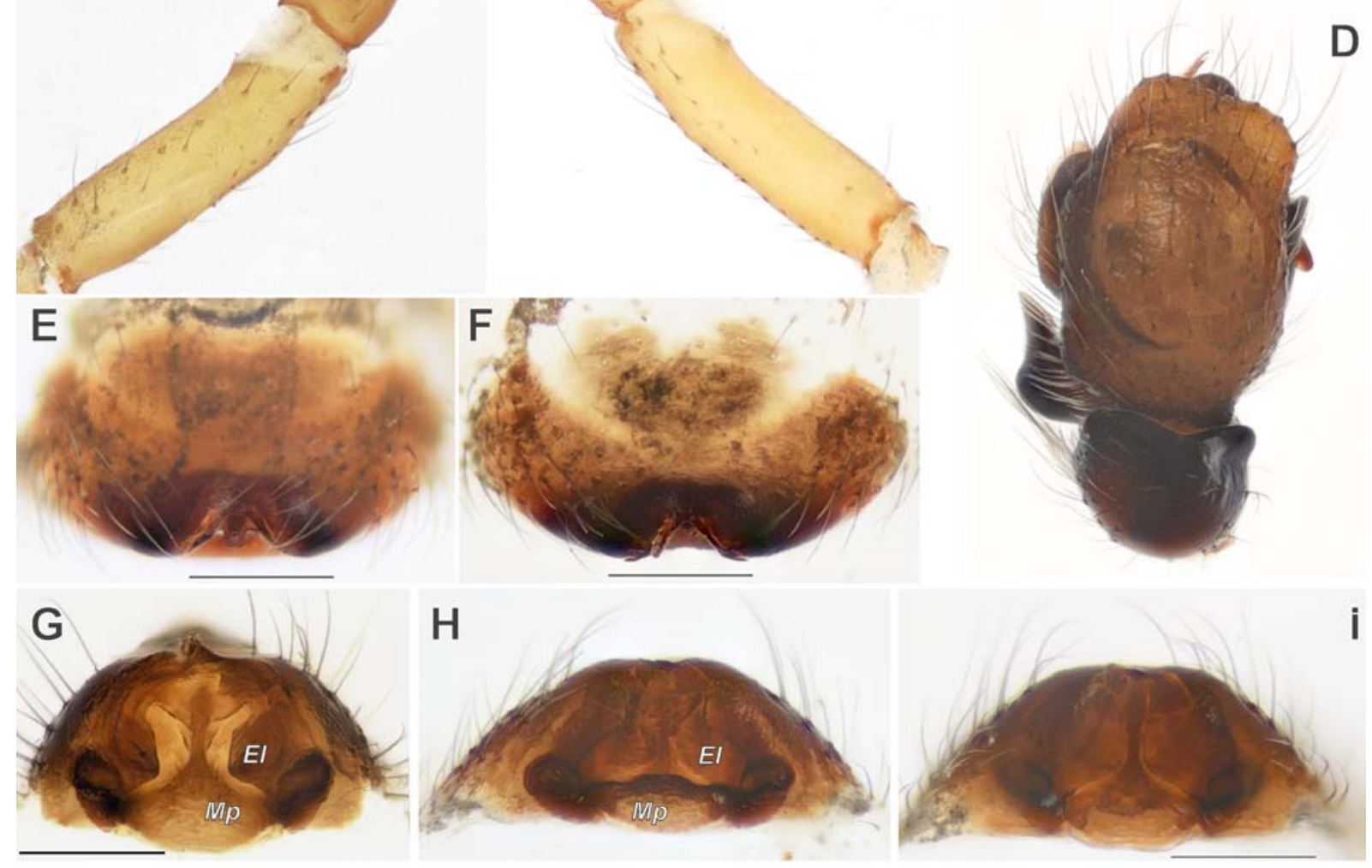

Fig. 2. Copulatory organs of Hilaira incondita. A, B - male palp, retro- and prolateral; C, D - terminal part of male palp, ventral and dorsal; E, F - epigyne of different specimens, ventral; G-I - epigyne, posterior. Scale $=0.2 \mathrm{~mm}$. Abbreviations: $\mathrm{Ct}$ - claw like tip of tibial apophysis, $E l$ - epigynal lobe, $M p$ - median plate.

Рис. 2. Копулятивные органы Hilaira incondita. А, В пальпа самца, ретро- и пролатерально; С, D - терминальная часть пальпы самца, вентрально и дорзально; E, F - эпигина разных особей, вентрально; G-I - эпигина, сзади. Масштаб 0,2 мм. Аббревиатуры: $C t$ - когтевидный отросток голени пальпы, $E l$ - лопасть эпигины, $M p$ - медиальная пластинка.

rounded tip; tegulum with small ventral extension $(V e)$; embolic division large, with massive and straight tail piece $(T p)$ and well separated embolus proper $(E m)$; embolus encircles embolic membrane $(\mathrm{Me})$ and forms $360^{\circ}$ loop; embolus proper broad except for filamentous terminal part.

Female. Total length $3.75-4.0 \mathrm{~mm}$, carapace $1.7-1.8$ long, 1.1-1.3 wide. Coloration and cheliceral teeth like in male. TmI 0.76-0.86.
Epigyne as in Figs. 3E-H, 6A-D; trilobate in ventral view and triangle shaped in antero-ventral view; fovea trapezoidal with distinct septum $(\mathrm{Se})$, septum itself with kind of median ridge $(\mathrm{Mr})$, septum visible through integument; median plate $(M p)$ trapezoidal, distal part wider than basal.

NOTE. Male palpal tibia has three apophyses. Prolateral and ventro-prolateral apophyses are not documented in other Hilaira species. 

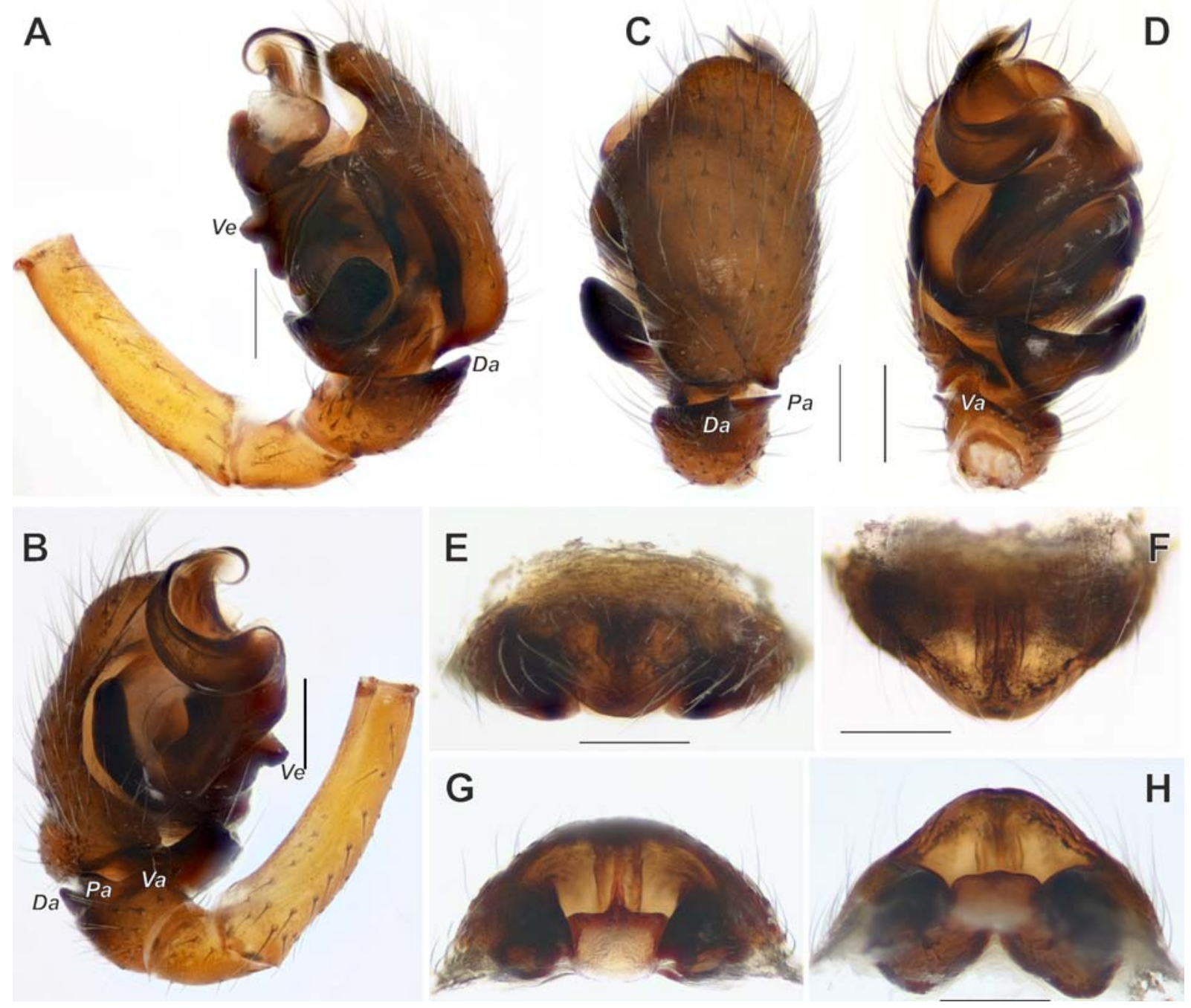

Fig. 3. Copulatory organs of Hilaira proletaria. A, B - male palp, retro- and prolateral; C, D - terminal part of male palp, dorsal and ventral; E, F - epigyne, ventral and antero-ventral; G, H - epigyne, posterior and dorso-posterior. Scale $=0.2 \mathrm{~mm}$. Abbreviations: $D a-$ dorso-prolateral tibial apophysis, $\mathrm{Pa}$ - prolateral tibial apophysis, $\mathrm{Va}$ - ventro-prolateral tibial apophysis, $\mathrm{Ve}$ - ventral extension of tegulum.

Рис. 3. Копулятивные органы Hilaira proletaria. А, В - пальпа самца, ретро- и пролатерально; C, D - терминальная часть пальпы самца, дорзально и вентрально; Е, F - эпигина, вентрально и антеровентрально; G, H - эпигина, сзади и сверху-сзади. Масштаб 0,2 мм. Аббревиатуры: $D a$ - дорзо-пролатеральный отросток голени, $P a-$ пролатеральный отросток голени, $\mathrm{Va}-$ вентро-пролатеральный отросток голени, $V e$ - вентральный вырост тегулюма.

DISTRIBUTION. The species has a Siberian-Nearctic range, and is known from Novaya Zemlya to Southampton Island in the Hudson Bay. All records of this species lie in the tundra zone (Fig. 7).

Acknowledgments. We are grateful to Mikhail Bizin and Boris Efeikin for providing us spiders from Yugorskiy Peninsula. We thank Ilari Sääksjärvi and Seppo Koponen (Zoological Museum, University of Turku) for providing us with museum facilities. The English of the final draft was edited Donald Buckle (Saskatoon, Saskatchewan, Canada). We thank the reviewers for their constructive comments. The study was supported in part by the Russian Foundation for Basic Research, Project \# 17-04-01603.

\section{References}

Eskov K.Yu. 1981. Taxonomy of spiders of the genus Hilaira (Aranei, Linyphiidae) // Zoologicheskii Zhurnal. Vol.60. No.10. P.1486-1493 [in Russian].

Eskov K.Yu. 1987. New data on spiders of the genus Hilaira (Aranei, Linyphiidae) in the fauna of the USSR // Zoologicheskii Zhurnal. Vol.66. No.7. P.1020-1031 [in Russian].

Holm Å. 1960. On a collection of spiders from Alaska // Zoologiska Bidrag från Uppsala. Vol.33. P.109-134.

Holm A. 1973. On the spiders collected during the Swedish expeditions to Novaya Zemlya and Yenisey in 1875 and $1876 / /$ Zoologica Scripta. Vol.2. No.2-3. P.71-110.

Hull J.E. 1932. Nomenclature of British linyphiid spiders: A brief examination of Simon's French catalogue // Transactions of the Northern Naturalists' Union. Vol.1. P.104-110. 

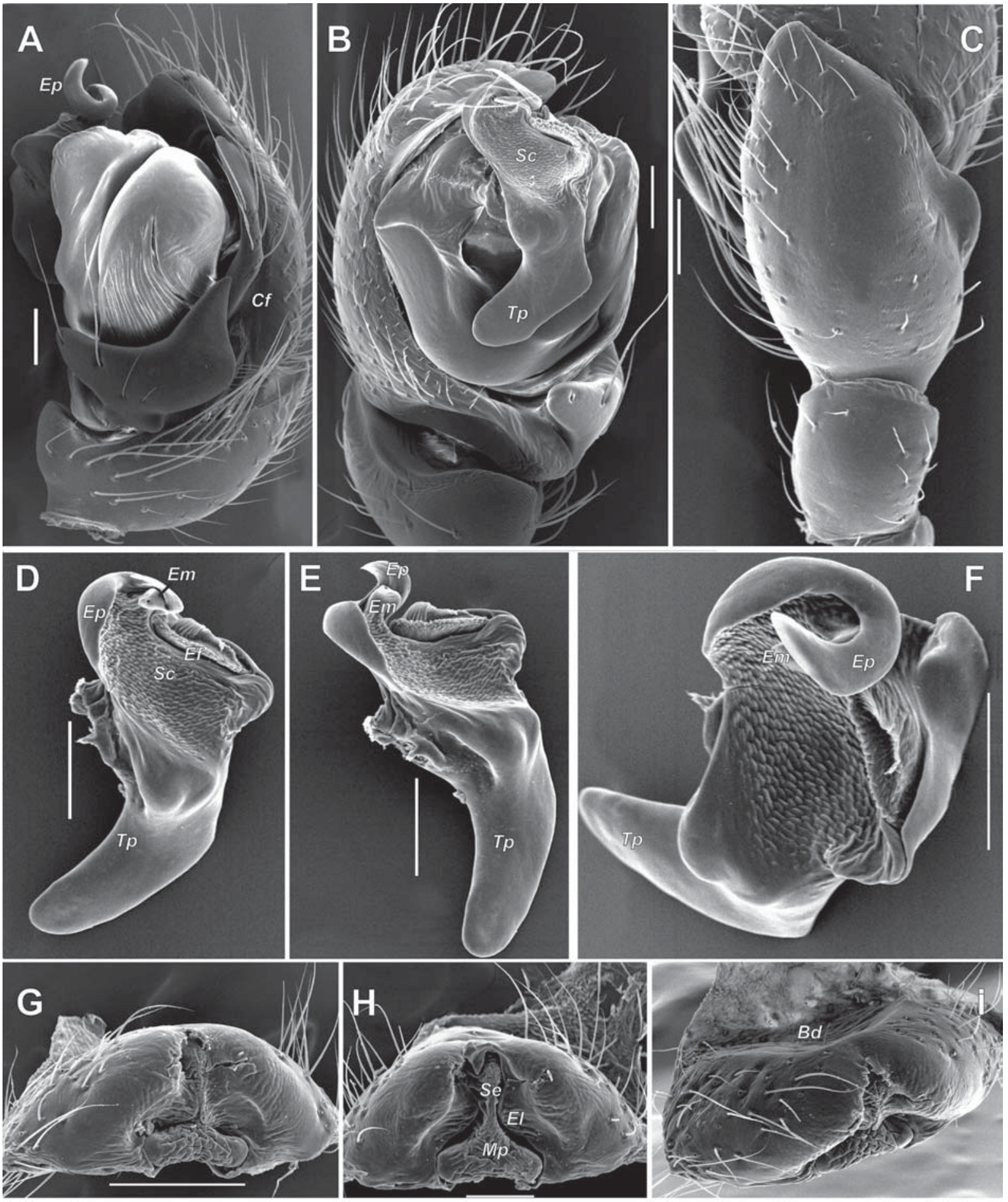

Fig. 4. SEM micrographs of Hilaira incondita copulatory organs. A, B - male palp, retrolateral and ventro-prolateral; C - male palpal patella and tibia, dorsal; D-F - embolic division, ventro-prolateral, ventral and anterior; G, H - epigyne, posterior; I - epigyne ventro-lateral. Scale $=0.1 \mathrm{~mm}$. Abbreviations: $B d$ - basal depression, $C f-$ cymbial fold, $E f-$ embolic longitudinal furrow, $E l-$ epigynal lobe, $E m$ - embolus proper, $E p$ — embolic process, $S c$ — scale like cuticle, $M p$ - median plate, $S e$ — septum, $T p$ — tailpiece of embolic division.

Рис. 4. СЭМ-микрофотографии копулятивных органов Hilaira incondita. А, В - пальпа самца, ретролатерально и вентропролатерально; C - колено и голень пальпы самца, дорзально; D-F - эмболюсный отдел, вентро-пролатерально, вентрально и спереди; G, H - эпигина, сзади; I - складка цимбиума, $E f$ - продольны шов эмболюса, $E l$ - лопасть эпигины, $E m$ - собственно эмболюс, $E p$ - вырост эмболюса, $S c$ - чешуйчатая кутикула, $M p$ - медиальная пластинка, $S e$ - септум, $T p-$ «хвост» эмблюсного отдела. 

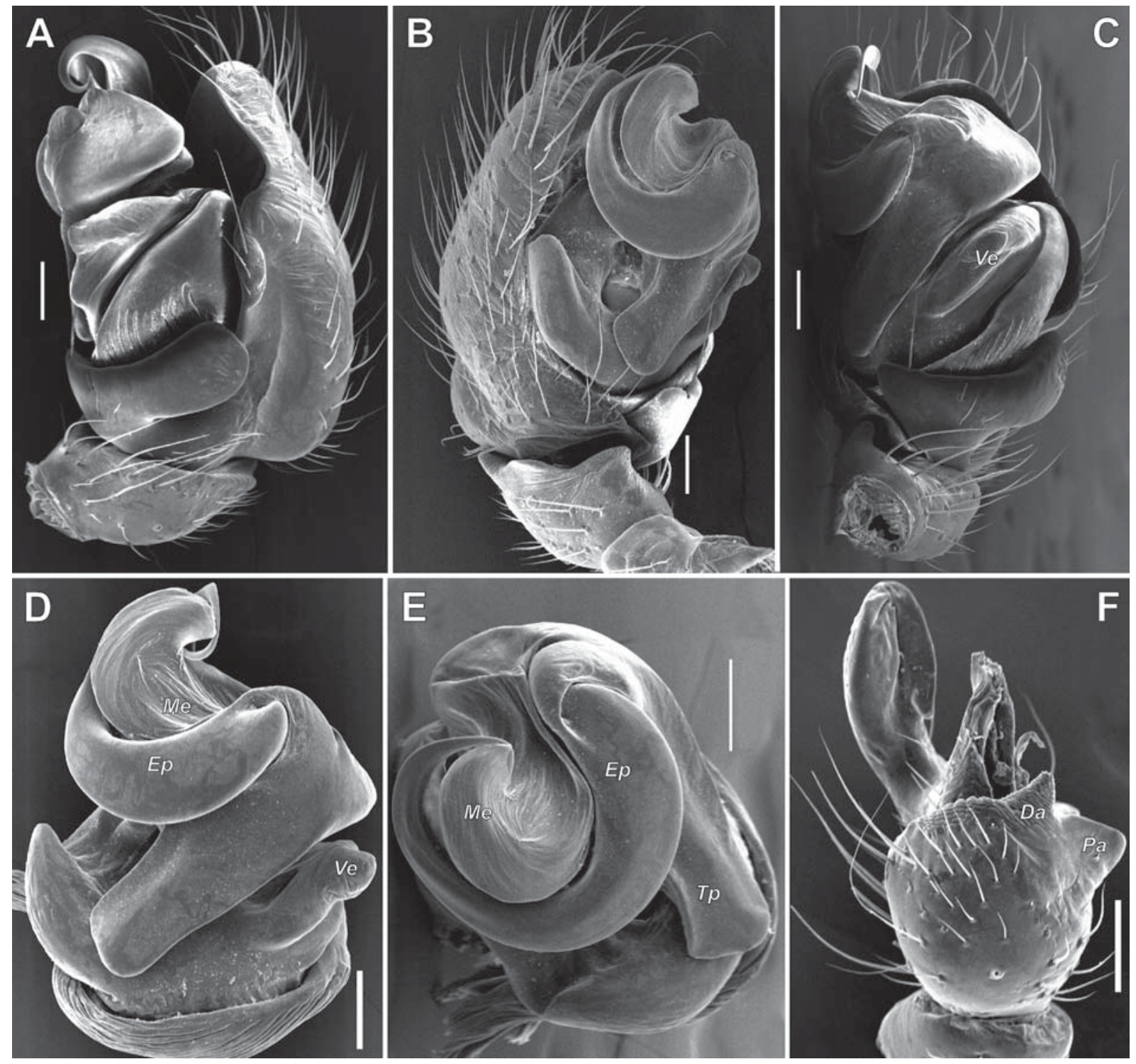

Fig. 5. SEM micrographs of Hilaira proletaria left male palp. A-C - retro-, prolateral and ventral; D, E - bulb, ventral and anterior; F - tibia and paracymbium, dorsal. Scale $=0.1 \mathrm{~mm}$. Abbreviations: $D a$ - dorso-prolateral tibial apophysis, $E p$ - embolic process, $M e-$ embolic membrane, $\mathrm{Pa}$ - prolateral tibial apophysis, $\mathrm{Tp}$ - tailpiece of embolic division, $\mathrm{Ve}$ - ventral extension of tegulum.

Рис. 5. СЭМ-микрофотографии левой пальпы самца Hilaira proletaria. A-C - ретро-, пролатерально и вентрально; D, E бульбус, вентрально и спереди; F — голень и парацимбиум, дорзально. Масштаб 0,1 мм. Аббревиатуры: $D a$ - дорсо-пролатеральный отросток голени, $E p$ - вырост эмболюса, $M e$ - эмболюсная мембрана, $P a-$ пролатеральный отросток голени, $T p-$ «хвост» эмблюсного отдела, $V e$ - вентральный вырост тегулюма.

Koch L. 1879. Arachniden aus Sibirien und Novaja Semlja, eingesammelt von der schwedischen Expedition im Jahre 1875 // Kongliga Svenska Vetenskaps-Akademiens Handlingar Bd.16. H.5. S.1-136.

Kulczyński W. 1908. Araneae et Oribatidae. Expeditionum rossicarum in insulas Novo-Sibiricas annis $1885-1886$ et 1900 1903 susceptarum // Zapiski Imperatorskoi Akademii Nauk St. Petersburg. Vol.18. No.7. P.1-97.

Kulczyński W. 1916. Araneae Sibiriae occidentalis arcticae // Mémoires de l'Académie Impériale des Sciences de Petrograd. Vol.28. No.11. P.1-44.
Marusik Yu.M., Tanasevitch A.V. 2003. Two new erigonine spiders (Aranei: Linyphiidae) from mountains of south Siberia // Arthropoda Selecta. Vol.11. No.2. P.159-165.

Saaristo M.I., Marusik Yu.M. 2004. Revision of the Holarctic spider genus Oreoneta Kulczyński, 1894 (Arachnida: Aranei: Linyphiidae) // Arthropoda Selecta. Vol.12. No.3-4. P.207249. [publ. July 16, 2004]

Simon E. 1884. Les arachnides de France. T.5. Pt.2 et 3. Paris: Roret. P.180-885.

Wiehle H. 1956. Spinnentiere oder Arachnoidea (Araneae). 28. Familie Linyphiidae-Baldachinspinnen // Die Tierwelt Deutschlands. Lfg.44. S.1-337. 

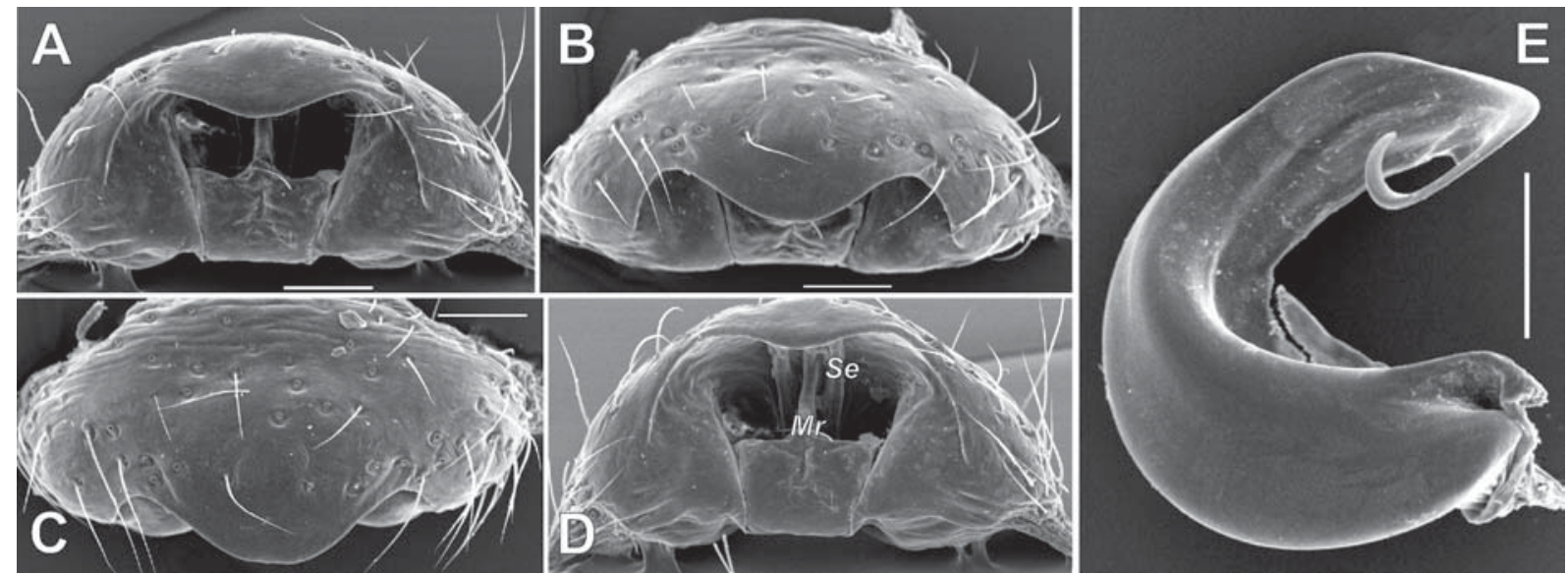

Fig. 6. SEM micrographs of Hilaira proletaria copulatory organs. A, B - epigyne, posterior and ventro-posterior; C, D - epigyne, ventral and posterior-dorsal; E - embolus proper, ventral. Scale $=0.1 \mathrm{~mm}$. Abbreviations: $M r$ - median ridge, $S e$ - septum.

Рис. 6. СЭМ-микрофотографии копулятивных органов Hilaira proletaria. А, В - эпигина, сзади и вентрально-сзади; С, D эпигина, вентрально и сзади-сверху; Е - собственно эмболюс, вентрально. Масштаб 0,1 мм. Аббревиатуры: $M r$ - ребро септума, Se - септум.

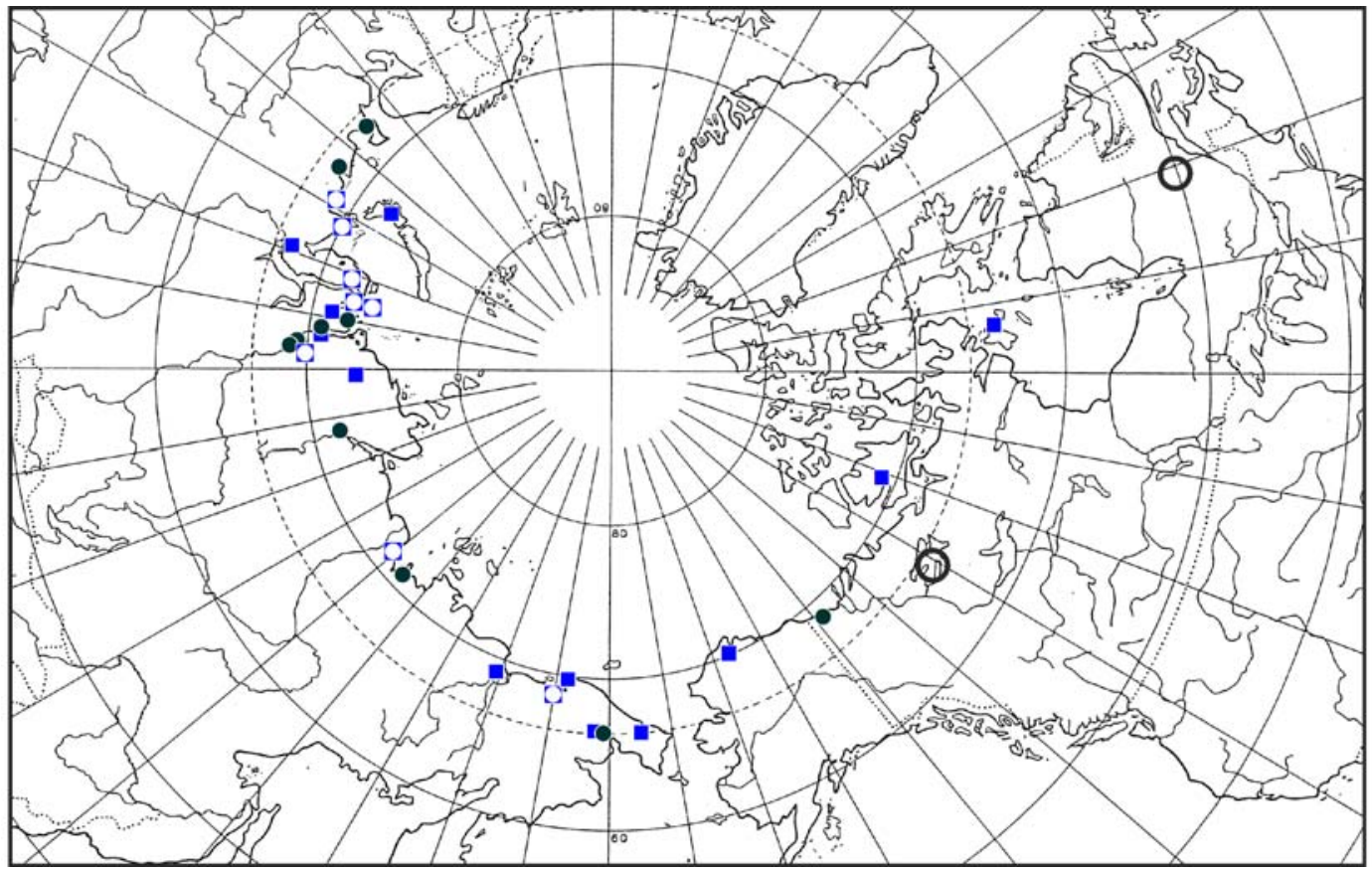

Fig. 7. Distribution records of Hilaira incondita (circle) and $H$. proletaria (square). Open signs refer to the territory or province records in Canada.

Рис. 7. Распространение Hilaira incondita (круг) и H. proletaria (квадрат). Незалитые значки обозначают наличие вида в административном выделе Канады.

WSC 2020. World spider catalog, version 20.5. Bern: Natural History Museum, online at http://wsc.nmbe.ch

Wunderlich J. 1983. Linyphiidae aus Nepal, IV. Bisher unbekannte und für Nepal neue Arten (Arachnida: Araneae) // Senckenbergiana Biologica. Vol.63. S.219-248. 